\title{
Comparison of the Aflatoxin levels in Fish Feeds from Rainbow Trout Farms Localized at Different Regions (Adana-Ağrı, TURKEY)
}

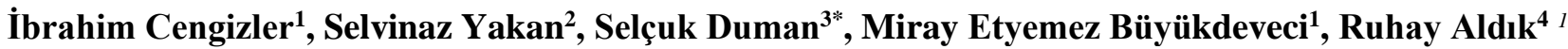 \\ ${ }^{I}$ Çukurova University, Faculty of Fisheries, Adana, Turkey \\ ${ }^{2}$ Ağrı İbrahim Çeçen University, Eleşkirt Celal Oruç School of Animal Production, Animal Health Department, \\ A $\breve{g r}$, Turkey \\ ${ }^{3}$ Çukurova University, Imamoğlu Vocational School, Fisheries Program, Adana, Turkey \\ ${ }^{4}$ Çanakkale Onsekiz Mart University, Applied Sciences College, Fisheries Technology Department, \\ Çanakkale, Turkey \\ icengiz@cu.edu.tr@, syakan@agri.edu.tr@, *sduman@cu.edu.tr@, metyemez@cu.edu.tr@, \\ ruhayaldik@comu.edu.tr@ \\ Received date: 05.02.2019 Accepted date: 25.10.2019
}

\begin{abstract}
Aflatoxins levels in different fish feeds obtained from two different rainbow trout (Oncorhynchus mykiss) farms located in Adana and Ağr1 regions were determined between May and July 2017. During the experiment period, "a drought status" was reported according to the Standardized Precipitation Index of Turkey by Turkish State Meteorological Service. According to precipitation index records, while Adana was reported as slightly humid, Ağrı was slightly dry in the period between May and July 2017. The aflatoxin analyses of fish feed samples was carried out in the laboratories of the Ministry of Food, Agriculture and Livestock in Adana, Turkey. The aflatoxin levels of the samples were resolved by liquid-solid extraction, immune-affinity pillar clean-up using a HPLC-FD (High Performance Liquid Chromatography with Fluorescence Detection). The detection limits of aflatoxin were 0.50, 0.23, 0.73, $0.20 \mathrm{ppb}$ for AFB1, AFB2, AFG1, AFG2, respectively. The results showed that, aflatoxin levels of fish feeds were below the detection limits in all samples.
\end{abstract}

Keywords: Aflatoxin, fish feed, HPLC analysis, rainbow trout farmtrout

\section{Farklı Bölgelerde (Adana-Ağrı, TÜRKIYYE) Bulunan Gökkuşağı Alabalığı Çiftliklerindeki Balık Yemlerinde Aflatoksin Düzeylerinin Karşılaştırılması}

$\ddot{O} z$

Mayıs ve Temmuz 2017 tarihleri arasında Adana ve Ağrı bölgelerinde bulunan iki farklı gökkuşağı alabalığı (Oncorhynchus mykiss) çiftliğinden elde edilen farklı balık yemlerinde aflatoksin seviyeleri belirlendi. Çalışmamıza ait dönemde Türkiye aylık standart yağış indeksine göre kuraklık durumu kaydedilmiştir. Kayıtlarımıza göre Ağrı ili Mayıs-Temmuz aylarında hafif kurak, Adana ili ise hafif nemli bir hava göstermiştir. Yem örneklerinin analizi T.C. Adana Gıda Tarım ve Hayvancılık Laboratuvarlarında yürütülmüştür. Numuneler floresan saptama (HPLC-FD) ile yüksek performanslı sıvı kromatografisi kullanılarak, sıvı-katı özütleme immune-affinity column clean-up metodu ile belirlenmiştir. Aflotoksin tespit limiti AFB1, AFB2, AFG1, AFG2 için sırasılyla 0,50;0,23;0,73;0,20 ppb, olarak belirlenmiştir. Örneklenen tüm balık yemlerinde aflatoksin düzeylerin tespit edilebilir değerin altında olduğu bulunmuştur.

Anahtar Kelimeler: Aflatoksin, balık yemi, HPLC analizi, gökkuşağı alabalığı çiftliği

\section{INTRODUCTION}

Aquaculture, husbandry of aquatic food organism, represents the fastest growing animal food-producing sector in many parts of the world. Rainbow trout (Oncorhynchus mykiss) is one of the most important freshwater fish species cultured in
Turkey and the total rainbow trout production was 101.166 tons in inland farms and 6.872 tons in marine environment in 2015 (TUIK, 2015). The increasing market demands to this species have promoted the feed industry to produce specifically formulated, higher quality feeds for rainbow trout. 
However, mycotoxin contamination is one of the most important obstacles in feed manufacturing industry. As the fish producers and feed manufacturers realize the mycotoxins significance and their potential effect on production, it becomes an essential topic for aquaculture (Gonçalves et al., 2018).

Mycotoxins are natural secondary toxic metabolites produced by fungi, particularly the moulds. The most detected mycotoxins in manufactured feeds are aflatoxin (AF), deoxynivalenol (DON), zearalenone (ZEN), ochratoxin A (OTA), fumonisins (FN), T-2 and HT2. Among these, AF are the most studied group of mycotoxins and are mainly produced by two species of the genus Aspergillus which are abundant particularly in areas with hot and humid climates (Marin et al., 2013). The most occurring forms of aflatoxins are AFB1, AFB2, AFG1 and AFG2. Aflatoxins are highly toxic and carcinogenic compounds that cause disease in animals and humans (Huang et al., 2010; Tsakiris et al., 2013). In particular, AFB1, the most hazardous aflatoxin can be produced by Aspergillus flavus, which affects the animals' growth performance due to the decrease in feed intake. In addition, the histopathological changes in observed in the liver tissue, immunosuppression, hepatotoxicity, mutagenicity were also reported in aquatic animals which cause fish mortalities (Ashley et al., 1965; Black and Baumann, 1991; Tacon, 1992; Richard, 2007; Han et al., 2010; Alinezhad et al., 2011; Rajeev et al., 2011). Baranyi et al. (2015), concluded that the presence of mycotoxins in feed depends on many factors including the season, temperature, humidity, region and the method of storage. Among them, climate is the most important factor for mycotoxin production. Fungi can produce a wide range of secondary metabolites resulting in production of aflatoxin under ecological conditions which are convenient for their growth. Various fungal strains need specific environment to produce mycotoxins and thus, routine monitoring of these toxins particularly in stored fish feeds is crucial in the fish farms where the humidity levels are high during the summer times.

This study was carried out to determine and compare aflatoxin levels of fish feeds samples, taken from rainbow trout farms in two climatologically different regions of Turkey.

\section{MATERIAL AND METHODS \\ The Origin of Samples and Sampling}

The fish feeds were taken from different rainbow trout farms located in Adana and Ağr1 regions over a period of three months (May-July 2017). Fish feed samples (500 grams) for four times each months have been moved to black bags in order to avoid exposure to the sun. The samplings were carried homogeneously by mixing original packed bags. Information concerning feed samples was noted as written in original feed bags.

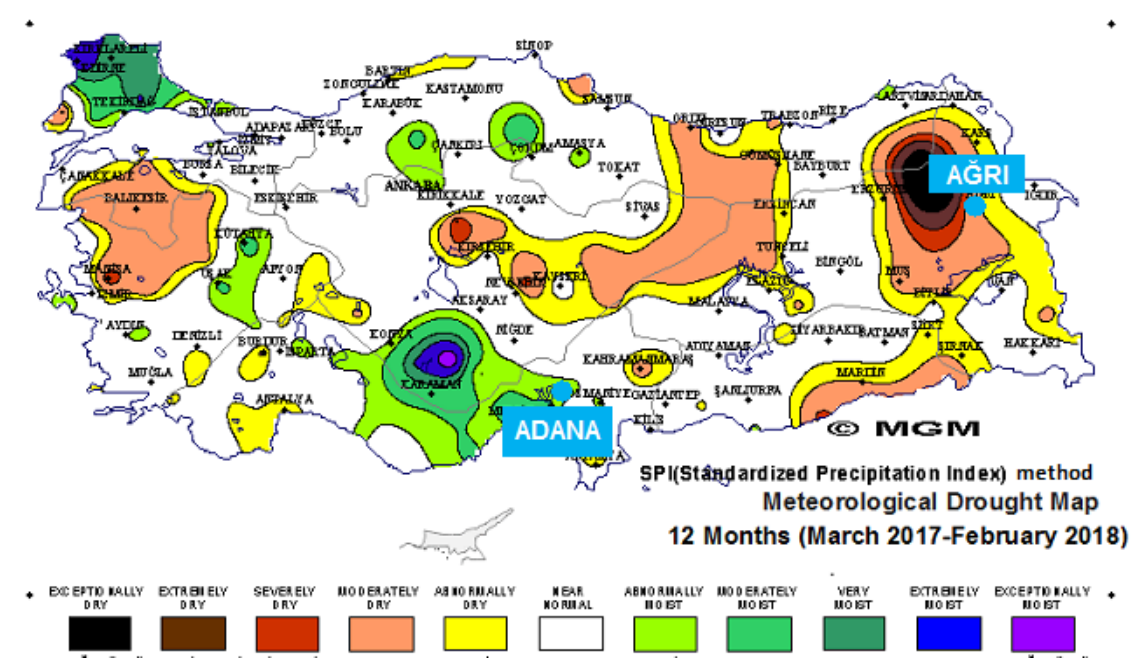

Figure 1. Turkey Standardized Precipitation Index (MGM, 2018) 
Figure1 shows 12-month comparative drought conditions in Turkey according to standard precipitation index of the Turkey. It reported that the
Ağrı region was slightly dry (Figure 2) while Adana/Kozan region was slightly humid (Figure 3) over the experiment period of three months.

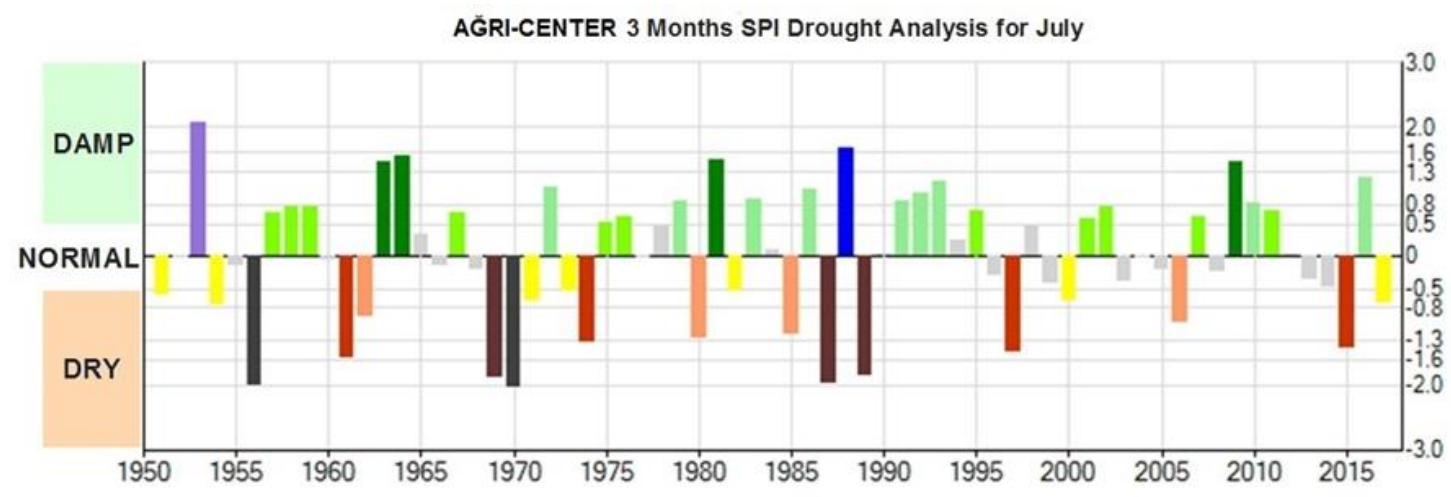

\begin{tabular}{lcc}
\multicolumn{3}{c}{ Number Percen } \\
\hline Extraordinary Moist & 1 & $\% 1.49$ \\
\hline Excessive Humidity & 1 & $\% 1.49$ \\
\hline Very Moist & 4 & $\% 5.97$ \\
Moderate Humidity & 9 & $\% 13.43$ \\
Lightly moist & 11 & $\% 16.42$ \\
Normal & 21 & $\% 31.34$ \\
Light Drought & 7 & $\% 10.45$ \\
Medium Dry & 4 & $\% 5.97$ \\
Severe Arid & 4 & $\% 5.97$ \\
Very Severe Drought 3 & $\% 4.48$ \\
Extraordinary Dry & 2 & $\% 2.99$ \\
Ambiguous & 0 & $\% 0.00$
\end{tabular}

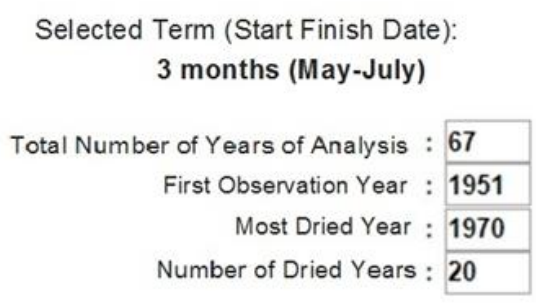

Figure 2. Drought Analysis in Ağrı (MGM, 2018)

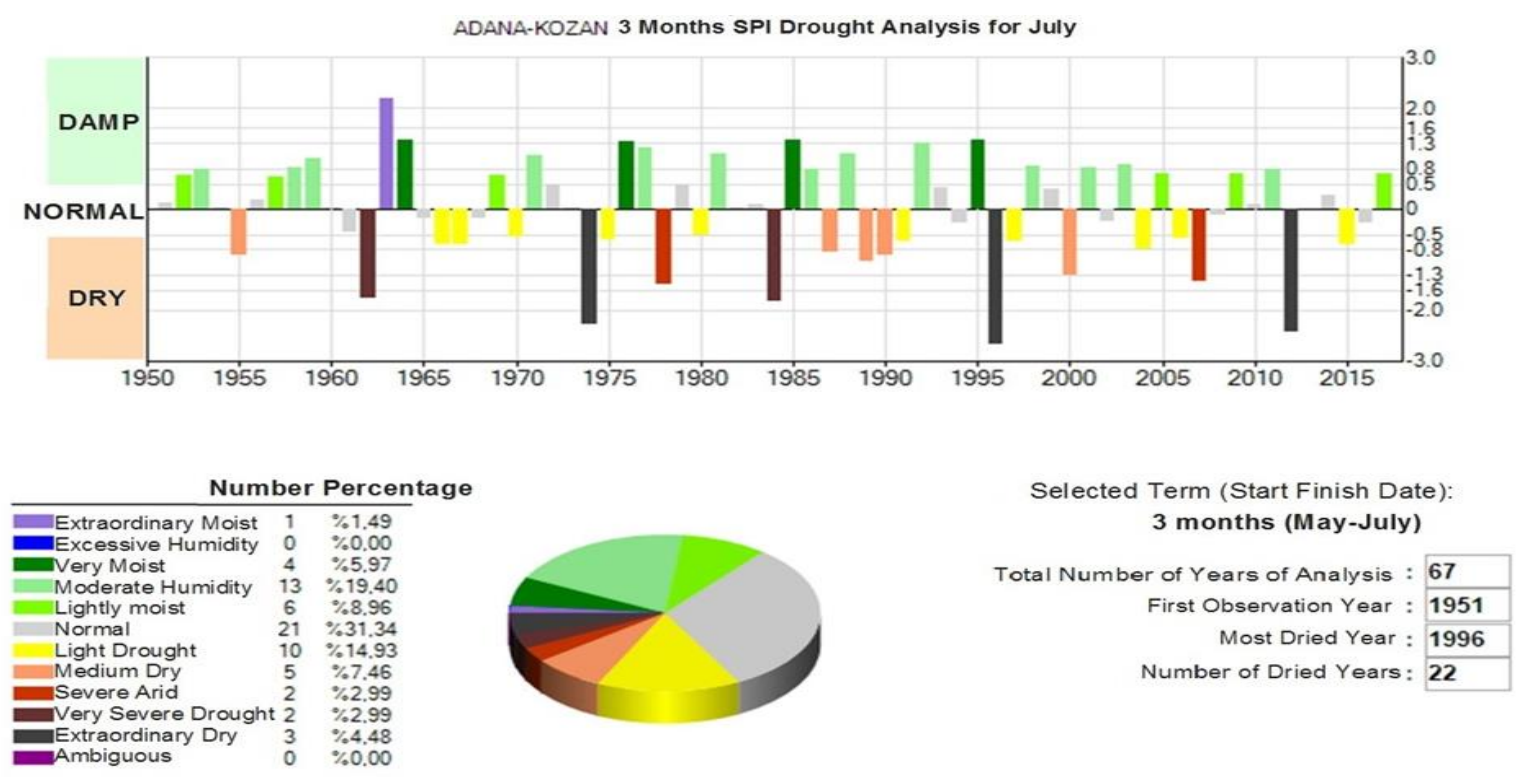

Figure 3. Drought Analysis in Adana/Kozan (MGM, 2018) 
Detailed information was also obtained about the environmental conditions in which the feed was kept. Temperatures were ranging from 14 to $35^{\circ} \mathrm{C}$. All the feed samples were homogeneously ground with blender and stored in a plastic container in a refrigerator until analysis. The analysis of feed samples was carried out in laboratories at the Ministry of Food, Agriculture and Livestock in Adana, Turkey.

\section{Extraction, HPLC-Apparatus and Conditions of Chromatography}

The aflatoxins were resolved by liquid-solid extraction, immune-affinity pillar clean-up using by a high performance liquid chromatography with fluorescence detection (HPLC-FD). The detection limit of the analysis was determined as $0.2 \mathrm{ppb}$ (Vicam, 2007). Fifty grams of fish feed samples were extracted with $100 \mathrm{~mL}$ methanol and $25 \mathrm{~mL}$ water byusing a blender at high speed for 1-2 min. Whatman No. 4 filter paper were used for filtration of the extract. A $10 \mathrm{~mL}$ aliquot of the filtrate was diluted with $40 \mathrm{~mL}$ ultrapure water, shaken vigorously and then filtered once more by a glass microfiber filter. The final volume of $10 \mathrm{~mL}$ filtrate was swiftly passed through column at a rate of 1-2 drop/sec. Afterward 2-3 mL air was passed through column.

AFs were separated from solvent by passing twice $1 \mathrm{ml}$ of methanol through the column at a flow rate of 2-3 mL min-1 and collected in vials. The column temperatures were retained at $35{ }^{\circ} \mathrm{C}$ for aflatoxins. The injection volume to HPLC apparatus for both standard and sample was $100 \mu \mathrm{L}$. For AFs analysis, the HPLC mobile phase was the mixed with the solution of water-acetonitrile-methanol $(6: 2: 3, \mathrm{v} / \mathrm{v} / \mathrm{v})$ and the flow rate was $1 \mathrm{~mL} \mathrm{~min}^{-1}$. Afterward, $120 \mathrm{mg}$ potassium bromide $(\mathrm{KBr})$ and $350 \mu \mathrm{L}$ nitric acid $\left(\mathrm{HNO}_{3} ; 65 \%\right)$ were added to 1 liter of mixed solution for electrochemical derivatization (Cobra Cell). The fluorescence detector was regulate to an excitation and emission wavelengths of 360 and $430 \mathrm{~nm}$. The total run time for one cycle was configured for $20 \mathrm{~min}$, and under these conditions, the retention times of AFB1, AFB2, AFG1 and AFG2 were 10.4, 8.7, 7.7 and 6.3 min, respectively.

\section{RESULTS AND DISCUSSION}

The liquid-solid extraction, immune affinity column clean-up in pursuit of HPLC-FD determination was performed to analyse the aflatoxin level in the fish feed samples. Figure 4 shows the level of aflatoxins (AF; sum of aflatoxin B1, B2, G1 and G2) in fish feeds, which were taken

from different rainbow trout farms, located in Adana and Ağrı regions over a period of three months (May-July 2017).

The detection limit of this analysis was determined $0.50 ; 0.23 ; 0.73 ; 0.20$ ppb for $\mathrm{B} 1, \mathrm{~B} 2$, G1, and G2, respectively. The results obtained from this study show that the aflatoxin levels in the feed samples during the research period was found below the detection limits in all fish feed samples.

Mycotoxin contamination of fish feed is a common problem in the countries with a humid tropical climates conditions that allow to mould growth. In addition, improper feed processing methods and storage conditions, which are suboptimal: temperatures about equal or higher than $27^{\circ} \mathrm{C}$, and moisture at levels greater than $14 \%$ cause mould growth (Santacroce et al., 2008; Russo and Yanong, 2010). In this current study, the Adana region is more humid, the aflatoxin B1 level was found lower in June. Gonçalves et al. (2017) were investigated 25 samples of finished fish feed which were obtained from Asia and Europe for mycotoxins. They were found that most of the feed samples were contaminated mainly by Fusarium mycotoxins. However, Hashimoto et al., 2003 were evaluated the aflatoxin and fumonisin (mycotoxin) contamination in 42 feed samples taken from the region of Londrina, Brazil. The aflatoxin levels ranged from non-detectable to $15.60 \mathrm{ppb}$, where $61.90 \%$ showed $<4$ ppb levels, which are in accordance with the Brazilian guideline (20 ppb). The fumonisin levels ranged from non-detectable to $11.2 \mathrm{ppb}$ and $76.20 \%$ samples were less than $4 \mathrm{ppb}$. Altuğ and Beklevik (2003) were analysed eightyfive samples taken from fish farming processes, feed factories and imported feeds for aflatoxin. As a result of the analyzes, they were found that total aflatoxin levels were in the range of 21.2-42.4 ppb in 20 feed samples, 5.0-20.0 ppb in 22 feed samples and below detection limits in 43 samples. Levels of aflatoxin were higher in samples taken from fish 


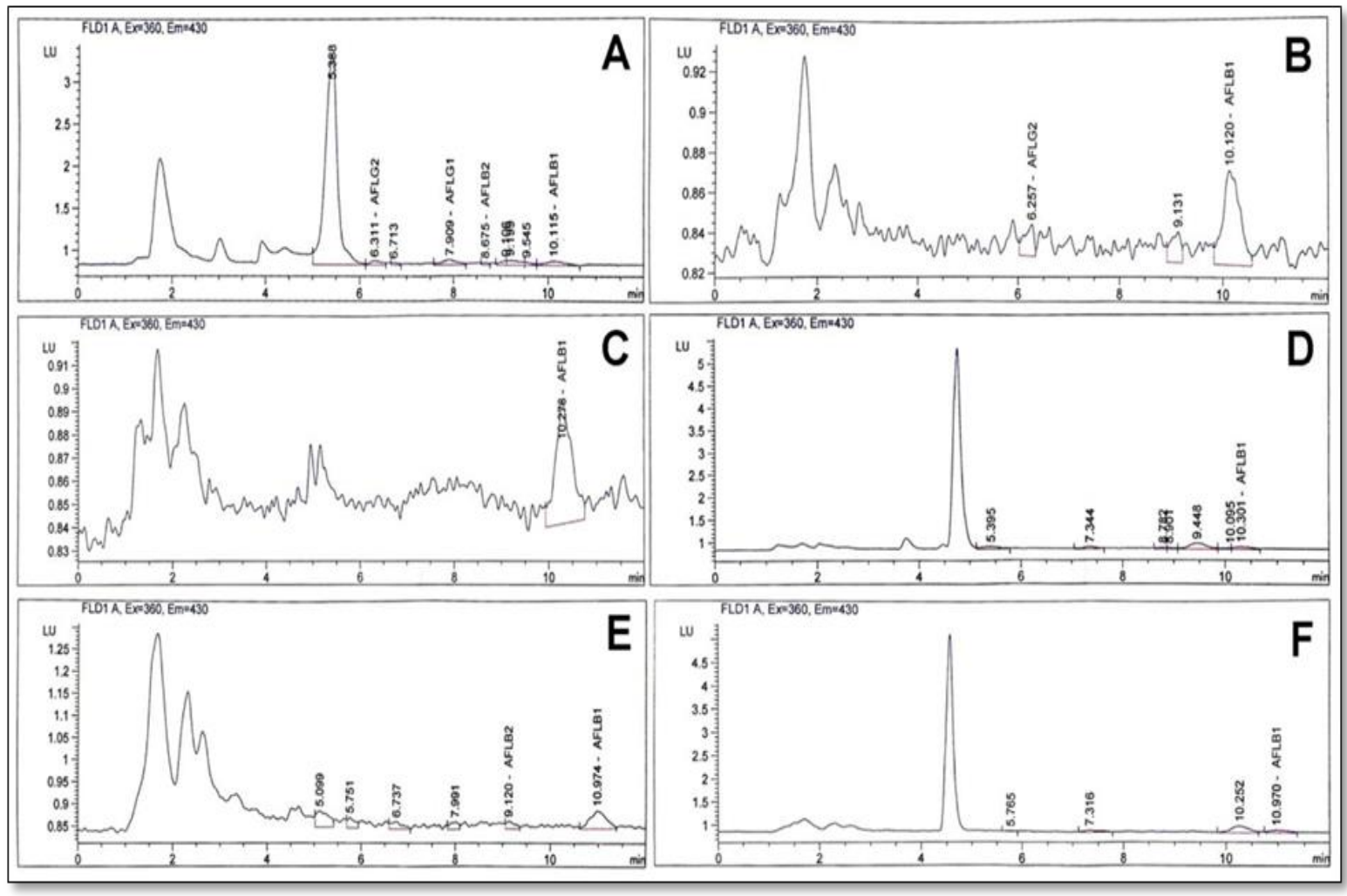

Figure 4. HPLC-FD Analysis results of the level of aflatoxins in fish feeds

A. The level of aflatoxins in fish feeds taken from Adana in May

B. The level of aflatoxins in fish feeds taken from Ağrı in May

C. The level of aflatoxins in fish feeds taken from Adana in June

D. The level of aflatoxins in fish feeds taken from Ağrı in June

E. The level of aflatoxins in fish feeds taken from Adana in July

F. The level of aflatoxins in fish feeds taken from Ağrı in July

farming processes than from factory or imported feed samples.

In this study although AFs levels in all fish feed samples was below the recommended limits (50 $\mathrm{ppb}$ ), it was important to underline the feed intake with toxin at low concentrations along the time since it produced chronic adverse effects in production of animal.

Due to adverse effects of aflatoxin, the limit values are applied in many countries in the framework of safe fish production of the farms in order to protect the consumers. Different countries have established a wide range of aflatoxin standards for fish feeds. The number of countries regulating mycotoxins has significantly increased over the years. Currently, more than 90 countries have adopted mycotoxin regulations for feed to limit mycotoxin exposure. According to aflatoxin standard used in Turkey in 2003, the maximum limits for all feedstuffs were $50 \mathrm{ppb}$ (Grace et al., 2015). However, Food and Drug Administration (FDA) has set the action levels for aflatoxins present in animal feeds as $20 \mathrm{ppb}$. Establishing legal maximum concentrations of mycotoxins does not indicate that mycotoxins are safe at low concentrations. In small quantities, mycotoxins may also interfere with normal cellular function and even lead to cell death and accumulated pathological changes (Bryden, 2012). It has been reported that aflatoxins at $0.01 \mathrm{ppb}$ levels in fish feed are capable of causing malignant tumours in fish (Cengizler, 2000). El-Sayed and Khalil (2009) described also that a prolonged oral administration of low levels of AFB1 $(0.018 \mathrm{mg} / \mathrm{kg}$ body weight $)$ to European seabass causes critical health problems and 
represents a major risk to consumers through aflatoxin residues in fish muscle.

\section{CONCLUSION}

At the present, the feed sector is not keeping pace with developments in disease control, anticontamination standards or animal genetic improvement. Further information and analysis are required for providing science-based solution to form a policy and the development of standards for fish feed. This study contributed increasing knowledge on presence aflatoxin levels in fish feeds for rainbow trout farm located in Adana and Ağr1, Turkey. Future studies could be conducted about fungi contamination and analyze the other mycotoxins such as fumonisins, zearalenone and ochratoxin A in fish feeds.

\section{ACKNOWLEDGMENTS}

We are grateful to all the laboratory members of the Ministry of Food, Agriculture and Livestock in Adana, Turkey for their technical advice and helpful discussion.

\section{REFERENCES}

Alinezhad, S., Tolouee, M., Kamalzadeh, A., Motalebi, A.A., Nazeri, M., Yasemi, M., ShamsGhahfarokhi, M., Tolouei, R., RazzaghiAbyaneh, M., 2011. Mycobiota and aflatoxin B1 contamination of rainbow trout (Oncorhynchusmykiss) feed with emphasis to Aspergillus section Flavi. Iranian Journal of Fisheries, 10(3):363-374.

Altuğ G., Beklevik G., 2003. Level of aflatoxin in some fish feeds from fish farming processes, feed factories and imported feeds. Turkish Journal of Veterinary and Animal Sciences, 27(6):1247-1252.

Ashley, L.M., Halver, J.E., Gardner, W.K., Wogan, G.N., 1965. Crystalline aflatoxins cause hepatoma. Federation Proceedings, Federation of American Societies for Experimental Biology, 24(2):627.

Baranyi, N., Kocsube, S., Varga, J., 2015. Aflatoxins: climate change and biodegradation. Current Opinion in Food Science, 5:60-66.

Black, J.J., Baumann, P.C., 1991. Carcinogens and cancers in freshwater fishes. Environmental Health Perspectives, 90:27-33.

Bryden, W.L., 2012. Mycotoxin contamination of the feed supply chain. Implications for animal productivity and feed security. Animal Feed Science and Technology, 173(1-2):134-158.
Cengizler, İ., 2000. Balık Hastalıkları Ders Kitabı. Ç.Ü. Su Ürünleri Fak. Yayın No: 7. 136s. Adana.

Conroy, G., 2000. Alteraciones asociadas condos alimentos comerciales en tetrahíbridos de tilapia roja cultivados en Venezuela. Caracas, Venezuela: Asociación Americana de Soya, 33.

El-Sayed, Y.S., Khalil R.H., 2009. Toxicity, biochemical effects and residue of aflatoxin B1 in marine waterreared seabass (Dicentrarchus labrax L.). Food and Chemical Toxicology, (47):1606-1609.

Grace, D., Lindahl, J., Atherstone, C., Kang'ethe, E., Nelson, F., Wesonga, T., Manyong, V., 2015. Aflatoxin standards for feed. Building an Aflatoxin Safe East African Community. Technical Policy Paper 7.

Gonçalves, R.A., Hofstetter, U., Schatzmayr, D., Jenkins, T., 2018. Mycotoxins in Southeast Asian aquaculture: plant-based meals and finished feeds. World Mycotoxin Journal, 11(2):265-275.

Gonçalves, R.A., Schatzmayr, D., Hofstetter, U., Santos, G.A., 2017. Occurrence of mycotoxins in aquaculture: preliminary overview of Asian and European plant ingredients and finished feeds. World Mycotoxin Journal, 10(2):183-194.

Han, D., Xie, S., Zhu, X., Yang, Y., Guo, Z., 2010. Growth and hepatopancreas performances of gibel carp fed diets containing low levels of aflatoxin B1. Aquaculture Nutrition, 16(4):335-342.

Hashimoto, E.H., Santos, M.A.D., Ono, E.Y.S., Hayashi, C., Bracarense, A.P.F.R.L., Hirooka, E.Y., 2003. Bromatologia e contaminação com fumonisina e aflatoxina em rações utilizadas na piscicultura da região de Londrina, Estado do Paraná, Brasil. Semina: Ciências Agrárias, 24(1): 123-132.

Huang, B., Han, Z., Cai, Z., Wu, Y., Ren, Y., 2010. Simultaneous determination of aflatoxins B1, B2, G1, G2, M1 and M2 in peanuts and their derivative products by ultra-high-performance liquid chromatography-tandem mass spectrometry. Analytica Chimica Acta, 662(1):62-68.

Hussein, H.S., Brasel, J.M., 2001. Toxicity, metabolism, and impact of mycotoxins on humans and animals. Toxicology, 167(2):101-134.

Marin, S., Ramos, A.J., Cano-Sancho, G., Sanchis, V., 2013. Mycotoxins: Occurrence, toxicology, and exposure assessment. Food and Chemical Toxicology, 60:218-237.

MGM, 2018. Meteoroloji Genel Müdürlüğü. Retrieved in March 30, 2018 from http://www.mgm.gov.tr.

Rajeev Raghavan, P., Zhu, X., Lei, W., Han, D., Yang, Y., Xie, S., 2011. Low levels of Aflatoxin B1 could cause mortalities in juvenile hybrid sturgeon, Acipenser ruthenus $\hat{\sigma} \times \mathrm{A}$. baeri $q$. Aquaculture Nutrition, 17(2):39-47. 
Richard, J.L., 2007. Some major mycotoxins and their mycotoxicoses-An overview. International Journal of Food Microbiology, 119(1-2):3-10.

Russo, J.R., Yanong, R.P., 2010. Molds in fish feeds and aflatoxicosis. Institute of Food and Agriculture Sciences, University of Florida. Gainesville, FL, USA.

Santacroce, M.P., Conversano, M.C., Casalino, E., Lai, O., Zizzadoro, C., Centoducati, G., Crescenzo, G., 2008. Aflatoxins in aquatic species: metabolism, toxicity and perspectives. Reviews in Fish Biology and Fisheries, 18(1):99-130.

Tacon, A.G., 1992. Nutritional fish pathology: morphological signs of nutrient deficiency and toxicity in farmed fish. Food \& Agriculture Org. FAO Fish Technical Paper. No. 330. Rome, p 75.

Tsakiris, I.N., Kokkinakis, E., Dumanov, J.M., Tzatzarakis, M.N., Flouris, A.D., Vlachou, M., Tsatsakis, A.M., 2013. Comparative evaluation of xenobiotics in human and dietary milk: persistent organic pollutants and mycotoxins. Cellular and Molecular Biology (Noisy-le-Grand, France), 59(1): 58-66.

TUIK, 2015. Türkiye İstatistik Kurumu. Su ürünleri istatistikleri. Retrieved in January 25, 2018 from http://www.tuik.gov.tr.

Vicam, 2007. AflaTest HPLC Instruction Manual. p 11. 